\title{
16
}

\section{Hydrodynamic Modeling of a Stormwater Pond for Optimal Sizing and Effectiveness}

\author{
Ray Dewey, Robert Flindall, David Crichton
}

\begin{abstract}
A two-dimensional, vertically averaged hydrodynamic model has been adapted to predict the circulation and sedimentation patterns in stormwater detention ponds or other water impoundment facilities. This model is an improvement over the existing plug flow models based on a series of constantly stirred tank reactors (CSTR) that cannot predict circulation patterns in ponds and reservoirs. The Circulation and Water Quality Model (CWQM) can identify areas in the pond where short-circuiting and dead zones occur. Sedimentation, based on firstorder decay, can be predicted. The sedimentation model is applied to an existing stormwater pond, and agreement was found between the predicted suspended solids (SS) concentration at the outlet and monitored outlet concentrations. Application of the model for evaluating a stormwater pond retrofit design is described below.
\end{abstract}

\subsection{Introduction}

The City of Toronto is undertaking a project to improve the water quality in Spring Creek, located on the east side of High Park, by improving the SS removal efficiency of two stormwater ponds at the upper end of the Creek. As part of the Class Environmental Assessment for the pond improvements, a hydrodynamic sedimentation model was developed and applied to evaluate the sediment-removal

Dewey, R., R. Flindall and D. Crichton. 2000. "Hydrodynamic Modeling of a Stormwater Pond for Optimal Sizing and Effectiveness." Journal of Water Management Modeling R206-16. doi:

10.14796/JWMM.R206-16.

(C) CHI 2000 www.chijournal.org ISSN: 2292-6062 (Formerly in Applied Modeling of Urban Water Systems. ISBN: 0-9683681-3-1) 
efficiency of the existing two-pond system and six alternative pond configurations. The retrofit condition and space constraints within the Spring Creek corridor necessitated the use of non-standard designs for the ponds. The results of the model simulation were used in conjunction with Ontario Ministry of the Environment (MOE) guidelines on sediment pond sizing to select a preferred design alternative that would meet the project's water quality objectives.

Current predictive models for estimating removal of settleable pollutants and for developing sizing guidelines represent a settling pond as a sequence of completely-mixed compartments, sometimes referred to as CSTRs (MOE 1994). These models rely on assumptions about hydraulic mixing and dispersion conditions within the pond that may not always be valid. Therefore, a hydrodynamic circulation model was developed to predict the water movement in stormwater ponds due to hydraulic forcing, bathymetry, shoreline geometry, and wind stress. The model, which is based on the two-dimensional, vertically averaged equations of momentum and continuity for estuaries and shallow waters, can also simulate the transport of conventional pollutants, decay of bacteria, and settling of suspended matter. Explicit representation of internal pond hydraulics is provided by the model, which does not rely on any assumptions that the flow regime is plug flow or completely mixed.

The hydrodynamic model can be applied to the design of proposed stormwater ponds, as well as sedimentation forebays for ponds. The computed circulation patterns, available as on-screen or printed output, provide a visual estimate of the level of effectiveness of the pond design in minimizing dead zones, eliminating short circuiting, and providing sufficient time for the settling of solids or decay of bacteria. Different settling rates of suspended particles can be computed by providing the gradation of the SS in the flow. The rates of accumulation of the different size particles can be simulated in the model, thereby providing a method to estimate the maintenance requirements for pond operation.

The dynamic model more accurately represents the flow pattern that governs where and how fast settling will occur than the more conventional plug flow or CSTR-type models. A multi-CSTR model cannot adequately represent the variable bathymetry and shoreline geometry that controls the circulation patterns. The effect of flow obstructions (such as islands for habitat development), deep zones for velocity equalization, and channelization cannot be properly represented with a plug flow or CSTR model.

\subsection{Hydrodynamic Model Formulation}

The model is based on the work by Leenderste and the Rand Corporation who developed the original model for analysis of the Jamaica Bay Estuary in New York City, New York (Leendertse, 1970, Leendertse and Gritton, 1971). The model 
was further refined during the construction of the massive Delta Works in the Netherlands. CH2M HILL's staff have been involved in the application and upgrading of this particular model for over 15 years. During several contracts for the MOE in the 1980s, the program was translated from a mainframe computer environment to the present form, running on desktop computers. Graphics and some menu features were also developed at that time.

For two-dimensional flow in well-mixed conditions, such as estuaries and shallow lakes, vertical integration of the momentum and continuity equations yields the following basic equations for the hydrodynamic model (ibid):

$$
\begin{gathered}
\frac{\partial U}{\partial t}+U \frac{\partial U}{\partial x}+V \frac{\partial U}{\partial y}-f V+g \frac{\partial \xi}{\partial x}+\frac{\tau_{x}^{b}}{\rho H}-\frac{\tau_{x}^{w}}{\rho H}-k\left(\frac{\partial^{2} U}{\partial x^{2}}+\frac{\partial^{2} U}{\partial y^{2}}\right)=0 \\
\frac{\partial V}{\partial t}+U \frac{\partial V}{\partial x}+V \frac{\partial V}{\partial y}+f U+g \frac{\partial \xi}{\partial y}+\frac{\tau_{y}^{b}}{\rho H}-\frac{\tau_{y}^{w}}{\rho H}-k\left(\frac{\partial^{2} V}{\partial x^{2}}+\frac{\partial^{2} V}{\partial y^{2}}\right)=0 \\
\frac{\partial \xi}{\partial t}+\frac{\partial(H U)}{\partial x}+\frac{\partial(H V)}{\partial y}=0
\end{gathered}
$$

where: $\quad U=$ speed in the $\mathrm{x}$ (longitudinal direction)

$\mathrm{V}=$ speed in the $\mathrm{y}$ (lateral direction)

$\mathrm{f}=$ Coriolis parameter $(1 / \mathrm{s})$

$\mathrm{g}=$ acceleration due to gravity $\left(\mathrm{m} / \mathrm{s}^{2}\right)$

$\mathrm{H}=\mathrm{h}+\xi(\mathrm{m})$

$\mathrm{k}=$ momentum dispersion coefficient

$\mathrm{h}=$ water depth at datum (m)

$\xi=$ water elevation above datum $(\mathrm{m})$

$\tau^{\mathrm{w}}{ }_{\mathrm{x}}, \tau^{\mathrm{w}}{ }_{\mathrm{y}}=$ wind stress component in $\mathrm{x}, \mathrm{y}\left(\mathrm{g} / \mathrm{m} / \mathrm{s}^{2}\right)$

$\tau^{b}{ }_{x}^{b}, \tau^{b}=$ bottom stress component in $x, y\left(g / m / s^{2}\right)$

$\rho=$ water density $\left(\mathrm{g} / \mathrm{m}^{3}\right)$.

The momentum dispersion term in Equations 16.1 and 16.2 was added during the upgrading by Leendertse. The wind stress equations are as follows:

$$
\tau^{\mathrm{w}}{ }_{\mathrm{x}}=\Phi \rho_{\mathrm{a}} \mathrm{w}^{2} \sin \psi \quad \tau_{\mathrm{y}}^{\mathrm{w}}=\Phi \rho_{\mathrm{a}} \mathrm{w}^{2} \cos \psi
$$

where:

$\Phi=$ wind stress coefficient, usually $=0.0026$

$\rho_{\mathrm{a}}=$ density of air $\left(\mathrm{g} / \mathrm{m}^{3}\right)$

$\mathrm{w}=$ wind velocity $(\mathrm{m} / \mathrm{s})$

$\psi=$ angle between the wind direction and the $\mathrm{x}$ axis 
The bottom stress components areas follow:

$$
\tau_{x}^{b}=\rho g U \frac{\sqrt{U^{2}+V^{2}}}{C^{2}} \quad \tau_{x}^{b}=\rho g V \frac{\sqrt{U^{2}+V^{2}}}{C^{2}}
$$

where: $\quad \mathrm{C}=$ Chezy Coefficient $\left(\mathrm{m}^{0.5} / \mathrm{s}\right)$

The Chezy coefficient $\mathrm{C}$ is determined at each grid point from:

$$
C=\frac{1.49}{N} H^{\frac{1}{6}}
$$

where: $\quad \mathrm{N}=$ Manning's $\mathrm{N}$ value

Land points are specified with a zero (0) Chezy value. Values for Manning's $\mathrm{N}$ are specified at each grid point. $\mathrm{N}$ is either constant throughout the grid or varied, depending on the specific conditions of each grid point. Smooth sand or flat bottoms will have a different bottom roughness than heavy aquatic growth or boulder-strewn bottoms. Most bottom conditions can be represented with this method. In addition, the Chezy coefficient can be recalculated at specified time periods to account for variable water depths due to flooding or drying of the grid points.

In the finite difference approximation of Equations 16.1, 16.2, and 16.3, the discrete values of the variables are described on a space-staggered grid, as shown below:

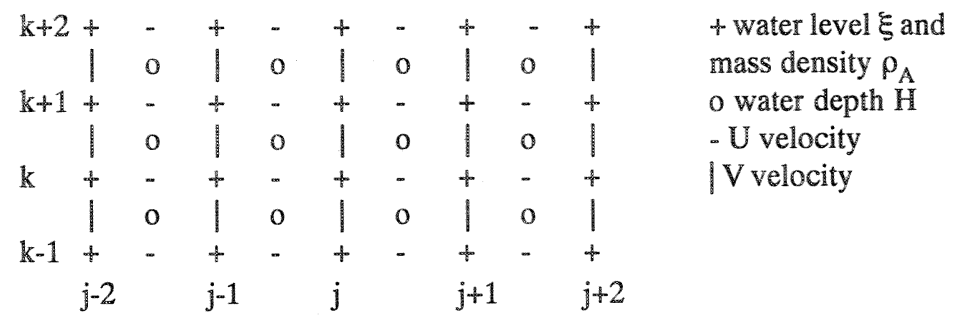

where the $x$ direction is represented by the $j$ index and the $y$ direction is represented by the $k$ index. The water level $\xi$ and mass density $\rho_{A}$ are computed at integer values of $j$ and $k$, while the values of $h$, obtained from hydrographic charts and field surveys, are given at half-integer values of $j$ and $k$. The velocities $U$ are computed at half integer values of $j$ and integer values of $k$, while the velocities $V$ are computed at half-integer values of $k$ and integer values of $j$. The solution of these equations in time is based on the split time formulation. 
The sequential use of the finite difference approximation to the momentum and continuity equations results in the use of the spatial derivatives forward and backward. Therefore, over a whole time step, the use of this procedure results in terms that are either central in time or averaged over that time interval.

The numerical solution of the finite difference equations presented above using the structure described has been shown to lead to stable solutions in both time and space (Leendertse 1970, Leendertse and Gritton, 1971). The basic mass balance equation for two-dimensional transport of a water quality parameter can be expressed as follows:

$$
\frac{\partial(H P)}{\partial t}+\frac{\partial(H U P)}{\partial x}+\frac{\partial(H V P)}{\partial y}-\frac{\partial\left(H D_{x} \frac{\partial P}{\partial x}\right)}{\partial x}-\frac{\partial\left(H D_{y} \frac{\partial P}{\partial y}\right)}{\partial y}+[K] H P+H S=0
$$

where:

$$
\begin{aligned}
P & =\frac{1}{H} \int_{-h}^{\xi} \rho_{A} d z \\
\rho_{\mathrm{A}} & =\text { mass density of substance } \mathrm{A}\left(\mathrm{g} / \mathrm{m}^{3}\right) \\
\mathrm{D}_{\mathrm{x}}, \mathrm{D}_{\mathrm{y}} & =\text { dispersion coefficients in } \mathrm{x} \text { and } \mathrm{y} \text { direction }\left(\mathrm{m}^{2} / \mathrm{s}\right) \\
\mathrm{S} & =\text { source or sink discharge }\left(\mathrm{g} / \mathrm{m}^{3} / \mathrm{s}\right) \\
{[\mathrm{K}] } & =\text { kinetic reaction array }\left(\mathrm{s}^{-1}\right)
\end{aligned}
$$

\subsubsection{Hydraulic Connectivity of Storm Ponds}

Storm ponds are hydraulically connected to downstream watercourses or other treatment ponds by some type of control structure, typically consisting of a weir, a submerged orifice, or a pump. The storm pond model can be set up with any number of source/sink grid connections. The model simulates a discharge by calculating the resulting water elevation increase in the grid point due to the increase in the volume of the cell. A grid point has an initial water depth of $h$ with a fluctuating water elevation of $\xi$, resulting in a final depth of $\mathrm{H}=\mathrm{h}+\xi$. If a grid point has a source of flow $S=1 \mathrm{~m}^{3} / \mathrm{s}$, then the change in volume over a time step $\Delta t$ of, for instance, 1 second is $1 \mathrm{~m}^{3}$. The change in $\xi$ is $1 \mathrm{~m}^{3}$ divided by the area of the grid point, which is the square of the grid size $\Delta x$. For a $5 \mathrm{~m}$ grid size, $\xi$ would change by $1 / 5^{2}$ or $0.04 \mathrm{~m}$ in one time step.

During each time step, the water elevation in the connecting grid points is monitored and, when the elevation exceeds a set level, then downstream flow commences. Rating curves derived the flow equations for the particular control structure are used to determine the volume of water to be removed from the upstream sink cell and to be added to the downstream source cell. 


\subsubsection{Sediment Removal}

The primary purpose of storm ponds is removal of pollutants, accomplished by sedimentation. Other processes, such as bacteria die-off and algal and aquatic plant uptake of soluble nitrogen and phosphorous, reduce the level of pollutants in the pond effluent.

Bacteria die-off is modeled as a first-order decay process. The MOE model has been used extensively in the past to simulate the bacteria levels in receiving waters. This model was used in the design of two combined sewer overflow (CSO) detention tanks and a CSO storage tunnel for the City of Toronto.

Sedimentation of SS can also be modeled as a first-order decay process, as follows:

$$
C=C_{0} e^{\left[-\frac{v_{s}}{Q / A}\right]} \text { or } C=C_{0} e^{(-k t)}
$$

where: $\quad \mathrm{v}_{\mathrm{s}}=$ settling velocity of particles $(\mathrm{m} / \mathrm{s})$

$\mathrm{Q} / \mathrm{A}=$ rate of applied flow divided by pond surface area $(\mathrm{m} / \mathrm{s})$

$\mathrm{k}=$ first-order decay constant $\left(\mathrm{s}^{-1}\right)$

$\mathrm{t}=$ residence time or in dynamic conditions time in pond (s)

$\mathrm{C}_{0}=$ initial concentration of stormwater influent $\left(\mathrm{g} / \mathrm{m}^{3}\right)$

This approach assumes that the flow is uniform over the water depth and turbulence in the vertical direction will not interfere with the particle's downward motion. In addition, there is no allowance for resuspension of settled material.

To accurately model the sedimentation process, some knowledge of particle size distribution and settling velocities must be known. For the model simulations undertaken, three particle sizes have been assumed - coarse, medium, and fine sediments. The decay constant, $\mathrm{k}$, is determined by estimating the time required to remove a certain percentage of the particle size (i.e. $\mathrm{C} / \mathrm{C}_{0}$ ) and solving Equation 16.6. The time to remove at least $90 \%\left(\mathrm{~T}_{90}\right)$ of the particle size provides reasonable values for $\mathrm{k}$ and is estimated by dividing the depth of the pond by the lower threshold velocity of each particle size.

Sediment accumulation is calculated by summing the amount of SS that is removed from each grid cell during each time step. The change in SS concentration by first-order decay is calculated in every grid cell for each time; therefore, the mass removed in one time step is as follows:

$$
\mathrm{M}=(\Delta \mathrm{x})^{2}(\mathrm{~h}+\xi) \Delta \mathrm{C}
$$

where:

$$
\begin{aligned}
\mathrm{M} & =\operatorname{mass} \text { removed }(\mathrm{g}) \\
\Delta \mathrm{x} & =\operatorname{grid} \operatorname{size}(\mathrm{m})
\end{aligned}
$$




$$
\begin{aligned}
\mathrm{h} & =\text { water depth at datum }(\mathrm{m}) \\
\xi & =\text { water depth above datum }(\mathrm{m}) \\
\Delta \mathrm{C} & =\text { change in concentration of } \mathrm{SS} \text { in grid point }\left(\mathrm{g} / \mathrm{m}^{3}\right)
\end{aligned}
$$

At this point in the development of the model, sediment build-up does not affect the water depth. This aspect of pond dynamics should be implemented if the particles are sufficiently coarse to form a solid bottom layer and bind with the existing surface material. The finer particles will require longer periods to consolidate; consequently, the impact of this component of the SS might be ignored in short simulations if conditions justify it.

\subsubsection{Circulation Patterns}

In hydrodynamic models, the velocity vector is essential for observing the currents simulated by the model. Usually the length of arrows is relative to some upper speed to provide sufficient resolution of the vectors. The authors break the range of speeds into three categories and display the arrows in different colours to identify areas of high-speed, average-speed and slow-speed water movement. Arrows with a fourth or fifth colour can identify speeds either above or below some threshold. For the black and white presentation, the arrow thickness has been varied and a gray scale used.

Pond designers can use information on water speeds to modify the pond shape and bathymetry to optimize the operation of the pond. Resuspension of previously settled solids that may occur in certain areas of a pond where water speeds are too high is not computed. Other areas in a pond may have speeds that are too slow, and SS may build up and alter the shape of the pond or affect the circulation. Dead zones and short-circuiting can be easily identified with this type of graphic information.

\subsection{Sedimentation Model Testing}

The application of any mathematical or computer model requires verification by comparison of the model output to real world data. To verify that the CWQM is valid, the model was used to simulate real runoff events through an existing stormwater management pond. The model results were compared to monitored TSS levels at the pond's inlet and outlet.

The Gloucester South Urban Community Stormwater Pond No. 1, located in Gloucester, Ontario, was designed in 1996. The first phase of construction was completed in 1997. At that time, Cell No. 5 and a temporary sediment forebay were constructed, as shown in Figure 16.1. The pond is operated as a wet pond with extended detention of runoff events. When fully developed, the pond's 


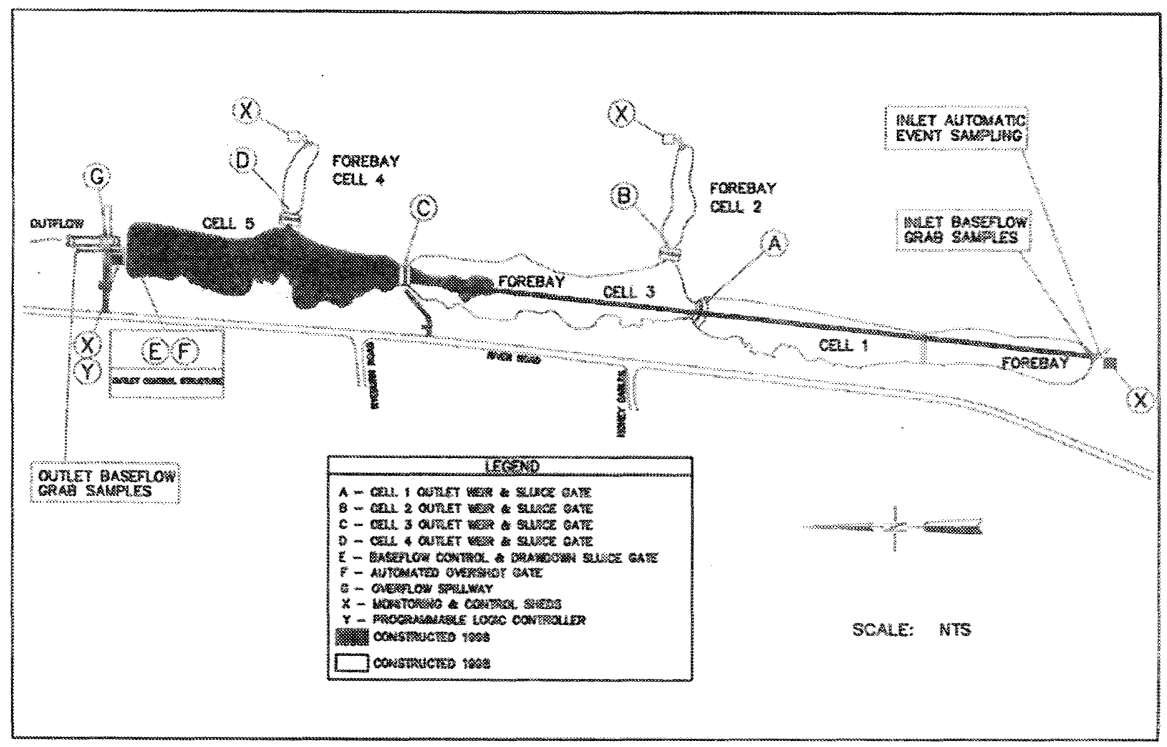

Figure 16.1 Gloucester SUC pond \#1.

drainage basin is expected to contain 6,000 dwelling units. The pond currently captures and treats stormwater runoff from the Urbandale and Richcraft subdivisions, currently under construction. A total of 310 building permits had been issued by the end of October 1998.

The City of Gloucester monitors the pond operations during the swimming season, from May 15 to September 15, as part of the requirements of the facility's Certificate of Approval (Sewage). Monitoring consists of automatic flow-paced sampling at the inlet and grab sampling at the pond outlet. The parameters monitored are bacteria (E.coli), total suspended solids (TSS), and phosphorous. This data provides an accurate measure of the inflow hydrograph, average inflow pollutant concentration, and a representative pollutant concentration at the outlet.

Two runoff events were chosen for verification from a total of 25 runoff events in the monitoring period. The events were selected to fulfill three criteriaa minimum of $72 \mathrm{~h}$ of antecedent dry weather; representative wet pool starting depth (the pond had been drawn down several times during the monitoring period); and sufficient runoff volume to activate storage in the pond. The chosen events are summarized in Table 16.1.

As noted previously, sedimentation is modeled as a first-order decay process. For the verification model runs, three pollutant species were used to simulate the entire range of solid particle sizes in the runoff. Each pollutant species is characterized by a different decay constant $k$. The decay constant for sedimentation was set such that the time to settle out $90 \%$ of each particle species $\left(\mathrm{T}_{90}\right)$ would be $0.25 \mathrm{~h}, 1 \mathrm{~h}$, and $16 \mathrm{~h}$, respectively. 
Table 16.1 Model verification - 1998 runoff events - Gloucester SUC pond \#1.

\begin{tabular}{lcc}
\hline Event Start Date (and Time) & July 9,1998 (21:25:00 h) & July 16, 1998 (17:05:00h) \\
\hline Antecedent Dry Weather & 103.5 hours & 140.5 hours \\
Runoff Event Duration & 22.83 hours & 2.17 hours \\
Runoff Event Volume & $1552 \mathrm{~m}^{3}$ & $604 \mathrm{~m}^{3}$ \\
Antecedent TSS Concentration & $7 \mathrm{mg} / \mathrm{L}$ (grab sample) & $3 \mathrm{mg} / \mathrm{L}$ (grab sample) \\
Average Inlet TSS Concentration & $612 \mathrm{mg} / \mathrm{L}$ (autosampler) & $638 \mathrm{mg} / \mathrm{L}$ (autosampler) \\
Final Outlet TSS Concentration & $9 \mathrm{mg} / \mathrm{L}$ (grab sample) & $1 \mathrm{mg} / \mathrm{L}$ (grab sample) \\
\hline
\end{tabular}

The Region of Ottawa-Carleton have developed a range of particle-settling velocities that are representative of sediments found in the region (Gore and Storie, 1993). These settling velocities are shown in Table 16.2. Included in Table 16.2, for comparison, are the settling velocities of particles reported in the U.S. Environmental Protection Agency NURP program and used in the EPA Methodology for Analysis of Detention Basins for Control of Urban Runoff (Driscoll et al., 1986). The Ottawa-Carleton settling velocity data were used to divide the influent TSS concentration between the three species according to their $\mathrm{T}_{90}$ velocities. Based on a pond depth that ranged between $1.16 \mathrm{~m}$ and $1.39 \mathrm{~m}$, the influent concentration was apportioned as shown in Table 16.3. The influent concentrations were held constant over the duration of the storm hydrograph.

Table 16.2 Settling velocity data.

\begin{tabular}{lcc}
\hline Mass Fraction & USEPA NURP Data $(\mathrm{m} / \mathrm{s})$ & Ottawa-Carleton Data $(\mathrm{m} / \mathrm{s})$ \\
\hline Coarsest $20 \%$ & 0.0055 & 0.0029 \\
Next $20 \%$ & 0.00059 & 0.001 \\
Next $20 \%$ & 0.00013 & 0.00038 \\
Next $20 \%$ & 0.000025 & 0.00015 \\
Finest $20 \%$ & 0.0000027 & 0.000022 \\
\hline
\end{tabular}

Table 16.3 Runoff TSS concentration distribution.

\begin{tabular}{ccc}
\hline Runoff Event & July 9, 1998 & July 16, 1998 \\
\hline TSS Concentration & $613 \mathrm{mg} / \mathrm{L}$ (Average) & $638 \mathrm{mg} / \mathrm{L}$ (Average) \\
$\mathrm{T}_{90} \leq 0.25$ hour & $245 \mathrm{mg} / \mathrm{L}(40 \%)$ & $223 \mathrm{mg} / 1(35 \%)$ \\
$\mathrm{T}_{90} \leq 1$ hour & $123 \mathrm{mg} / \mathrm{L}(20 \%)$ & $160 \mathrm{mg} / \mathrm{L}(25 \%)$ \\
$\mathrm{T}_{90} \leq 16$ hour & $245 \mathrm{mg} / \mathrm{L}(40 \%)$ & $255 \mathrm{mg} / \mathrm{L} \mathrm{(40 \% )}$ \\
\hline
\end{tabular}

The TSS concentrations at a grid point on the pond centre line near the inlet and outlet are shown on Figures 16.2 and 16.3. These figures show the initial dilution of the influent concentration and the final concentration following sedimentation. The summation of the particle concentrations at the end of the simulations corresponds well with the sample data. Detailed studies of observed sediment build-up rates and long-term simulations would be required to further validate the model. 


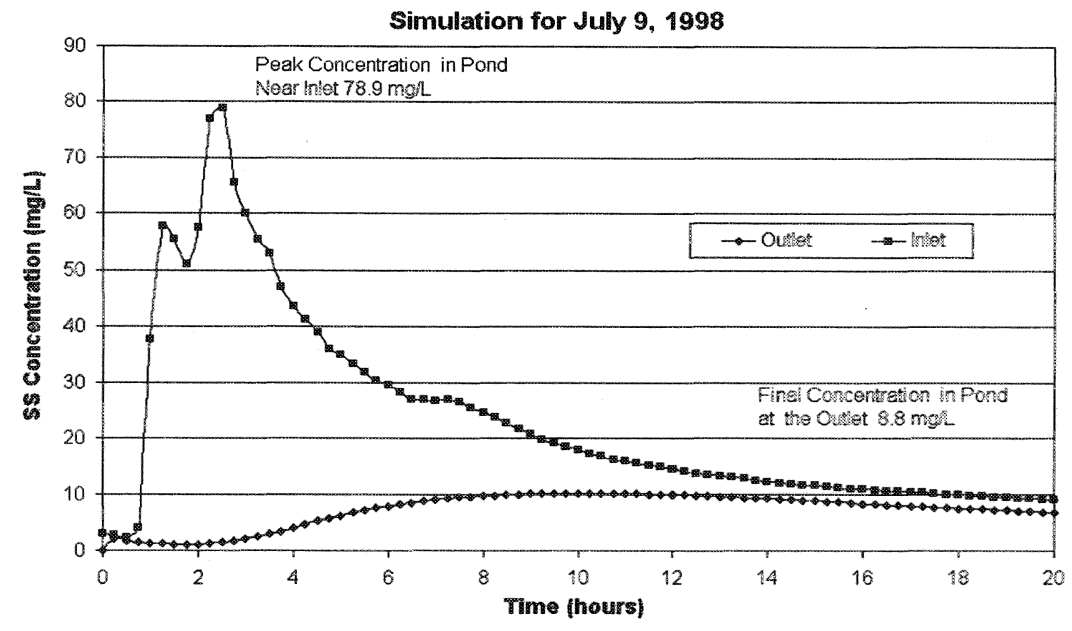

Figure 16.2 CWQM simulation of the July 9, 1998 event.

Simulation for July 16, 1998

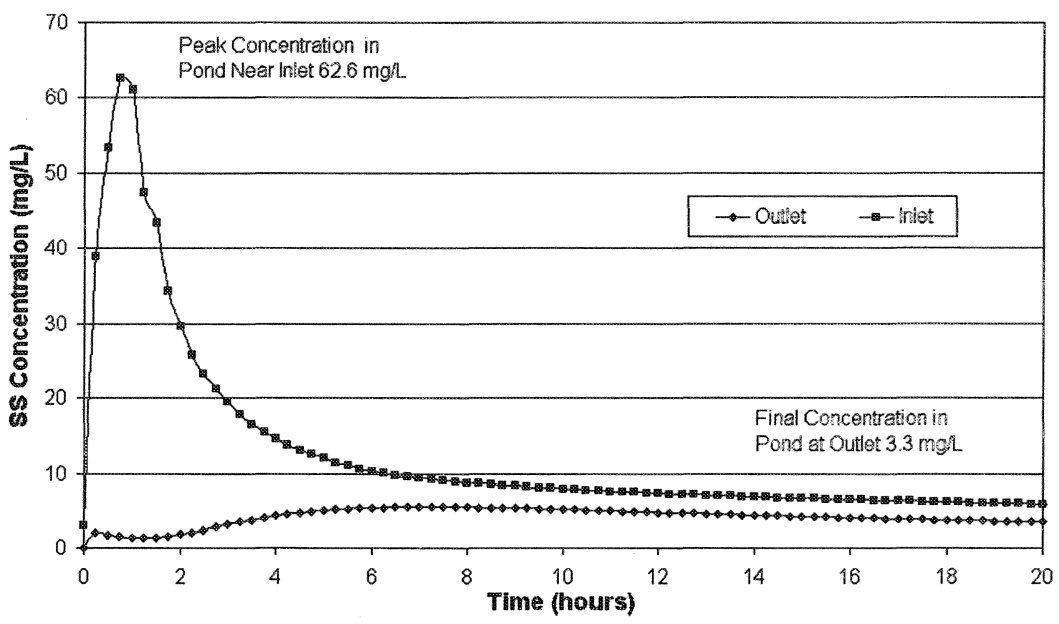

Figure 16.3 CWQM simulation of the July 16, 1998 event. 


\subsection{City of Toronto - Spring Creek Sedimentation Pond Improvements}

The CWQM was employed to evaluate the effectiveness of proposed retrofit improvements to the Spring Creek sedimentation ponds. A sedimentation model was required for this purpose because the existing pond system and the retrofit alternatives did not closely resemble the configuration of the generic facilities described in the MOE design guidelines (MOE 1994). An accurate evaluation of each retrofit alternative was necessary due to limited space for expansion and improvement of the ponds resulting from the presence of environmentally sensitive vegetation communities, steep topography, and existing utilities within the Spring Creek valley.

The existing system, shown in Figure 16.4, consists of two permanent pool ponds separated by an overflow weir. The upper (north) pond has a surface area of approximately $1625 \mathrm{~m}^{2}$ with a design depth of $0.91 \mathrm{~m}$. The upper pond discharges over a $4.8 \mathrm{~m}$ long weir, built as part of a footbridge at the south end of the pond. The existing lower pond has a surface area of approximately 1400 $\mathrm{m}^{2}$ and a design depth of $0.46 \mathrm{~m}$. The lower pond discharges over a $3.7 \mathrm{~m}$ long weir, also built in conjunction with a footbridge. The ponds receive stormwater inflows from a 248 ha urban drainage area via two storm sewers that discharge at the north end of the upper pond. All of the flow entering the upper pond must pass over the first weir before entering the lower pond. Neither of the ponds has a separate low-flow discharge mechanism.

In total, the two ponds have a permanent pool storage volume of approximately $2125 \mathrm{~m}^{3}$ and an active storage volume of $1945 \mathrm{~m}^{3}$ before overtopping their banks. The ponds do accumulate large quantities of sediment, but their overall efficiency is likely not greater than $30 \%$ removal of the TSS load in the runoff they receive. The MOE design guidelines call for a TSS removal efficiency of $70 \%$ removal for Type 3 Fish Habitat and a minimum of $50 \%$ removal of TSS for retrofit situations. The City of Toronto's draft Sewer System Master Plan, Phase III (April, 1992) recommends the provision of $14,000 \mathrm{~m}^{3}$ of storage for treatment of runoff from a $25 \mathrm{~mm}$ rainfall event with $24 \mathrm{~h}$ of extended detention, along with control of floatables, oil, and grease.

The Class Environmental Assessment of the proposed improvements to the Spring Creek ponds identified five alternative structural solutions to the problem, in addition to numerous best management practices and the do nothing alternative. The structural solutions considered were new or retrofitted sedimentation ponds, new constructed wetlands, new subsurface storage tanks, high flow rate swirl concentrators, and diversion of flows to the Wendingo Creek pond. The preferred alternative of retaining and improving the existing ponds was selected as it provides reasonable efficiency for sediment removal with moderate costs and has minimal effect on the existing natural environment. 


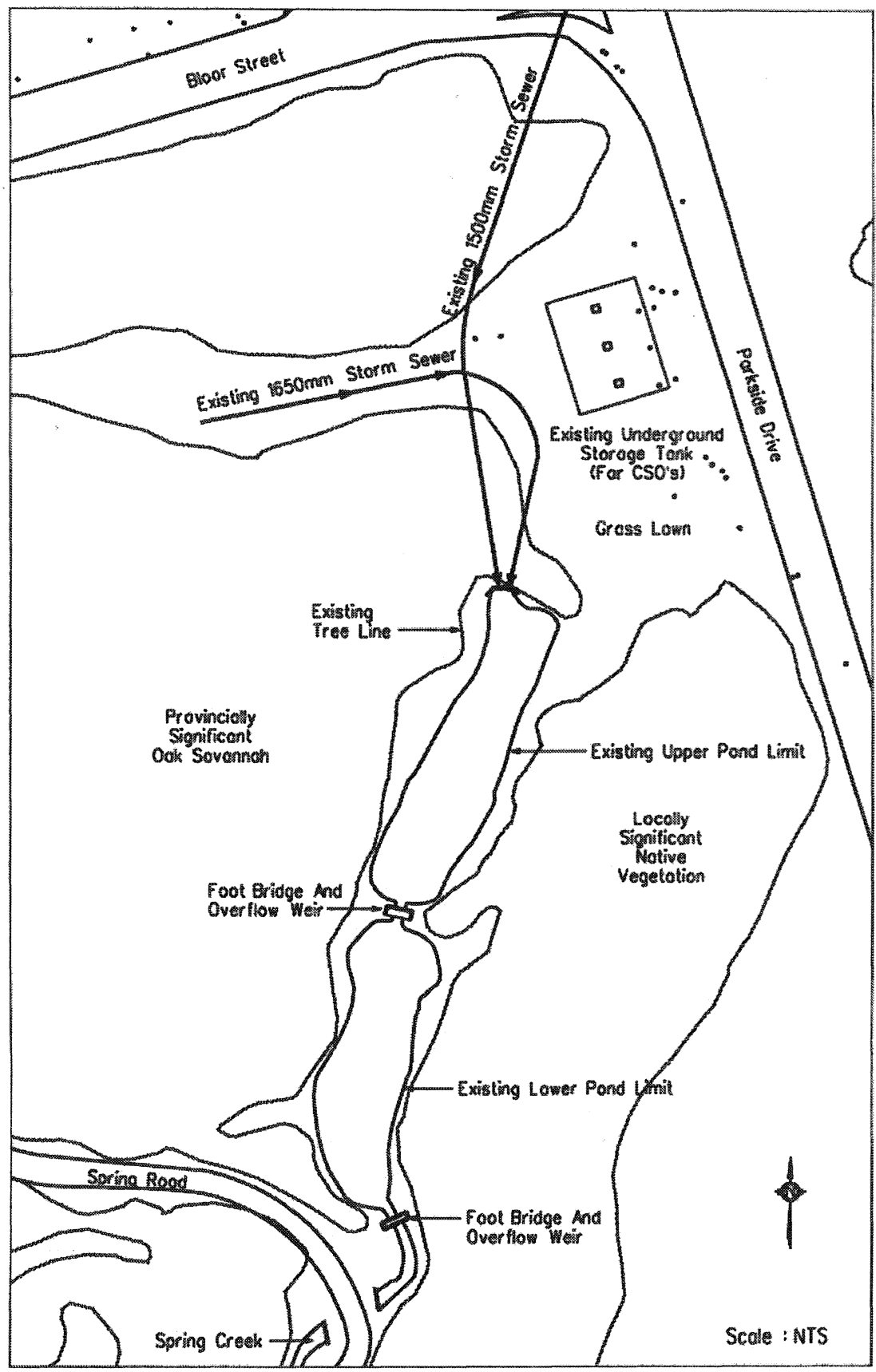

Figure 16.4 Spring Creek existing conditions. 


\subsubsection{Design Alternatives}

The existing sedimentation ponds, utilities, structures, and vegetation in the surrounding area have been outlined in Figure 16.4. Six alternative designs for expanding and improving the efficiency of the existing ponds were evaluated for the Environmental Study Report.

\section{Alternative 1: Deepen the Existing Ponds}

The existing pond depths range from $0.46 \mathrm{~m}$ to $0.91 \mathrm{~m}$. Alternative 1 involves deepening the north pond to a depth of $2.0 \mathrm{~m}$ and the south pond to a depth of $1.85 \mathrm{~m}$. The south pond is shallower due to the need to protect existing utilities that cross under the pond.

\section{Alternative 2: Deepen and Expand the Existing Ponds (while avoiding native vegetation)}

Alternative 2 involves deepening the north pond to a depth of $2.0 \mathrm{~m}$ and the south pond to a maximum depth of $1.85 \mathrm{~m}$, as well as expanding the size of the ponds to the greatest extent possible while still protecting provincially- and locallysignificant vegetation communities. The requirement to expand the ponds while protecting native vegetation produced a somewhat irregular pond outline. The presence of existing buried utilities in the pond area also resulted in irregular pond invert elevations in the upper pond, including a shallow shelf area that is $0.65 \mathrm{~m}$ deep. This option was eventually selected as the preferred design alternative, following screening in the Environmental Study Report. Figure 16.5 shows the limits of the revised ponds.

A similar option (referred to as Alternative 2A) involves deepening and expanding the ponds to the same limits as in Alternative 2 and includes revising the overflow structures from each pond to provide additional extended detention and a separate low-flow discharge from the ponds.

\section{Alternative 3: Deepen and Expand the Existing Ponds (while avoiding native vegetation) and Construct a Third Pond North}

Alternative 3 includes the same features as Alternative 2 with respect to the existing ponds, with the additional construction of a third treatment cell in the grass lawn area north of the existing ponds. The new pond would have a permanent pool and allow extended detention of a portion of the stormwater flows before overflowing into the existing upper pond. Elevation constraints would allow only one of the existing storm sewers to discharge into the new cell; the other sewer would continue to discharge into the enlarged upper pond. Treated water from new cell would discharge into the revised upper cell. 


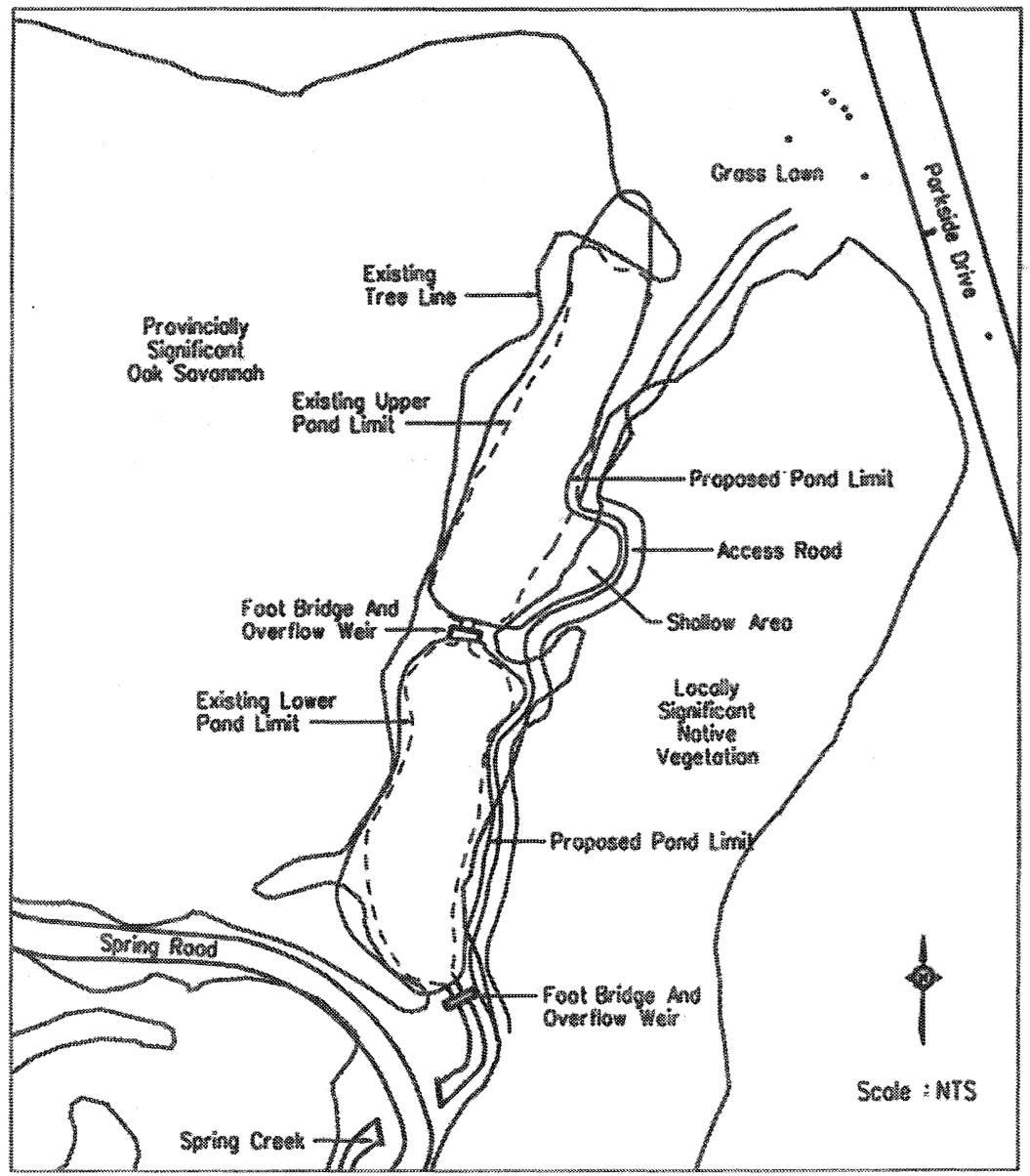

Figure 16.5 Spring Creek design alternatives 2 and 2A.

Alternative 4: Deepen And Expand the Existing Ponds (while avoiding native vegetation) and Utilize the Existing Combined Sewer Standby Storage Tank

Alternative 4 includes the same features as Alternative 2 with respect to the existing ponds and also utilizes an existing combined sewer standby storage tank to provide additional extended detention storage. Once retrofitted, the storage tank would add approximately $4,000 \mathrm{~m}^{3}$ of storage to the system. Elevation constraints would allow only one of the existing storm sewers to be diverted for discharge into the retrofitted tank; the other sewer would continue to discharge into the existing upper pond. Portions of the flow from the diverted storm sewer would bypass the tank and enter the existing upper pond to avoid surcharging the tank. The tank would discharge treated water back into the upper pond. 
Alternative 5: Deepen and Expand the Existing Ponds to the Maximum Extent and Construct a New Pond

For this alternative, the north and south ponds would be deepened to $2.0 \mathrm{~m}$ and $1.85 \mathrm{~m}$, respectively, and expanded to a point where a $4: 1$ (horizontal to vertical) slope could be constructed to match the existing ground. Existing buried utilities in the upper pond area resulted in irregular invert elevations. A new treatment cell would be constructed in the grass lawn area north of the existing ponds, as described for Alternative 3. Elevation constraints would allow only one of the existing storm sewers to discharge into the new cell; the other sewer would continue to discharge into the enlarged upper pond. Treated water from the new cell would discharge into the revised upper cell.

\subsubsection{Evaluation of Alternatives with MOE Design Guidelines}

The MOE Stormwater Management Practices, Planning and Design Manual (1994) provides the storage requirements for wetlands, wet ponds, and dry ponds (both batch mode and continuous-flow mode) based on the receiving water's quality objectives. The prescribed volumes are expressed as $\mathrm{m}^{3}$ per hectare of drainage area for a range of impervious levels. For wetlands and wet ponds, a total storage volume is given, of which $40 \mathrm{~m}^{3} /$ ha represents extended detention storage and the remainder represents permanent pool volume.

Each of the alternative designs described in the previous section is compared to the MOE guideline volumes, as outlined in Table 16.4 .

Table 16.4 Analysis of available treatment volumes for storage alternatives by MOE guidelines.

\begin{tabular}{|c|c|c|c|c|c|c|}
\hline \multirow[b]{2}{*}{ Alternative } & \multicolumn{3}{|c|}{$\begin{array}{l}\text { Available Volume Based on } \\
\text { Design Assumptions }\end{array}$} & \multicolumn{3}{|c|}{$\begin{array}{l}\text { Percent of MOE Guideline Volume } \\
\text { for } 60 \% \text { TSS Removal }\end{array}$} \\
\hline & $\begin{array}{c}\text { Total } \\
\mathrm{m}^{3}\end{array}$ & $\begin{array}{c}\text { Permanent } \\
\text { Pool } \\
\mathrm{m}^{3}\end{array}$ & $\begin{array}{c}\text { Extended } \\
\text { Detention } \\
\mathrm{m}^{3}\end{array}$ & $\begin{array}{c}\text { Total } \\
\%\end{array}$ & $\begin{array}{c}\text { Permanent } \\
\text { Pool } \\
\%\end{array}$ & $\begin{array}{c}\text { Extended } \\
\text { Detention } \\
\%\end{array}$ \\
\hline Existing Ponds & 4,070 & 2,125 & 1,945 & 27.4 & 42.8 & 19.6 \\
\hline Alternative 1 & 6,850 & 4,840 & 2,010 & 46.0 & 97.6 & 20.3 \\
\hline Alternative 2 & 10,345 & 7,165 & 3,180 & 69.5 & 144.0 & 32.0 \\
\hline Alternative $2 \mathrm{~A}$ & 9,870 & 3,435 & 6,435 & 66.3 & 69.2 & 64.9 \\
\hline Alternative 3 & 14,475 & 8,575 & 5,900 & 97.3 & 172.8 & 59.5 \\
\hline Alternative 4 & 14,345 & 7,165 & 7,180 & 96.4 & 144.0 & 72.4 \\
\hline \multirow[t]{3}{*}{ Alternative 5} & 18,235 & 10,750 & 7,485 & 122.5 & 150.9 & 108.4 \\
\hline & & & & $81.7^{*}$ & $60.4^{*}$ & $108.4^{*}$ \\
\hline & & & & \multicolumn{3}{|c|}{ *70\% TSS Removal Guideline } \\
\hline
\end{tabular}


Several difficulties exist with using the MOE guideline volumes to evaluate the effectiveness of each retrofit option for sediment removal. These uncertainties are listed below:

- It is unclear from Table 16.4 whether any of the retrofit alternatives, with the exception of Alternative 5, would achieve the desired removal efficiency, since none of the alternatives matches the guideline volumes for permanent pool and extended detention volume.

- The guidelines were derived from modeling a single treatment cell (completely mixed conditions) with specific depths and geometry. All of the alternatives include two or more treatment cells in series. The depth and geometry of the cells are not exactly the same as the guidelines due to design constraints.

- The guidelines assume that each facility employs only one sediment settling mechanism. This assumption is not valid for some of the alternatives examined. For example, Alternative 4 employs a continuous-flow tank, a wet pond with a shallow shelf area, and a wet pond with no shallow regions.

- The guidelines assume $24 \mathrm{~h}$ drawdown of the active storage (extended detention); this was not provided in any of the alternatives. Alternatives 3, 4, and 5 assume a $12 \mathrm{~h}$ drawdown time only in the new treatment cell or tank, with much shorter drawdown times in the retrofitted ponds. Alternative $2 \mathrm{~A}$ assumes a $12 \mathrm{~h}$ drawdown of the extended detention in the retrofitted ponds.

\subsubsection{Sediment Removal Efficiency Predicted by the Circulation and Water Quality Model}

To overcome the difficulties noted with evaluating the retrofit alternatives, the CWQM was used to assess the sediment-removal efficiency of each alternative. This analysis could then be used in conjunction with the MOE guidelines, along with other evaluation criteria, when selecting the preferred design alternative for the Environmental Study Report.

The City of Toronto provided hydrographs for the two storm sewers discharging to the existing pond for both $26.7 \mathrm{~mm}$ and $13 \mathrm{~mm}$ storm events. No time series of stormwater SS levels for the design storms were available, so the concentration of SS was assumed to be $150 \mathrm{mg} / \mathrm{L}$. This value had been previously measured as an average for various wet weather events in Toronto by the MOE and was confirmed by samples collected from the two storm sewers entering the ponds (City of Toronto 1998). 
Three different sediment sizes were modeled, based on particle distribution measurements of sediment collected from the MacLean Avenue stormwater detention in the City of Toronto tank and from Grenadier Pond in High Park. The concentrations of each particle size were proportioned as $85 \mathrm{mg} / \mathrm{L}, 45 \mathrm{mg} / \mathrm{L}$, and $20 \mathrm{mg} / \mathrm{L}$, with decay rates equivalent to $90 \%$ settling out in $2 \mathrm{~h}, 10 \mathrm{~h}$, and $24 \mathrm{~h}$, respectively, as determined from the settling velocities used in the MOE guidelines.

The pond systems were modeled at a resolution of $2 \mathrm{~m}$ and a time step of $1 \mathrm{~s}$. Each storm pond modeled used a combination of submerged orifices and broad-crested weirs as flow control structures. The initial water elevations, weir heights, and orifice dimensions were based on existing drawings and proposed structural changes.

The model accumulated the sediment trapped by the pond system for each particle size. The total load of sediment to the system was integrated from the hydrograph and SS concentration. The $26.7 \mathrm{~mm}$ event had a total load of $2.548 \mathrm{t}$ and the $13 \mathrm{~mm}$ event had a total load of $1.162 \mathrm{t}$. The predicted accumulation of sediment was used to provide an overall efficiency of each pond option. Table 16.5 lists the accumulated sediment and the resulting efficiency of each pond system for these two storms.

Table 16.5 Sediment removal efficiency computed by modeling.

\begin{tabular}{|c|c|c|c|c|c|c|}
\hline \multicolumn{7}{|c|}{ Accumulated Sediment (tonnes) } \\
\hline Alternative & Storm Event & $\begin{array}{c}\mathrm{T}_{90}=2 \mathrm{~h} \\
(85 \mathrm{mg} / \mathrm{L})\end{array}$ & $\begin{array}{l}\mathrm{T}_{90}=10 \mathrm{~h} \\
(45 \mathrm{mg} / \mathrm{L})\end{array}$ & $\begin{array}{l}\mathrm{T}_{90}=24 \mathrm{~h} \\
(20 \mathrm{mg} / \mathrm{L})\end{array}$ & $\begin{array}{c}\text { Total } \\
\text { Removed }\end{array}$ & $\begin{array}{l}\text { Percent Removal } \\
\text { Efficiency } \\
(\%)\end{array}$ \\
\hline \multirow[t]{2}{*}{ Existing } & $26.7 \mathrm{~mm}$ & .658 & .125 & .031 & .814 & 31.9 \\
\hline & $13 \mathrm{~mm}$ & .396 & .125 & .031 & .552 & 47.5 \\
\hline \multirow[t]{2}{*}{ Alternative 1} & $26.7 \mathrm{~mm}$ & .827 & .211 & .048 & 1.086 & 42.6 \\
\hline & $13 \mathrm{~mm}$ & .479 & .152 & .040 & .671 & 57.7 \\
\hline \multirow[t]{2}{*}{ Alternative 2} & $26.7 \mathrm{~mm}$ & .879 & .225 & .053 & 1.157 & 45.4 \\
\hline & $13 \mathrm{~mm}$ & .494 & .150 & .042 & .686 & 59.0 \\
\hline \multirow[t]{2}{*}{ Alternative $2 \mathrm{~A}$} & $26.7 \mathrm{~mm}$ & .789 & .191 & .046 & 1.026 & 40.2 \\
\hline & $13 \mathrm{~mm}$ & .450 & .142 & .035 & .627 & $53.9^{\circ}$ \\
\hline \multirow[t]{2}{*}{ Alternative 3} & $26.7 \mathrm{~mm}$ & 1.036 & .275 & .037 & 1.342 & 52.6 \\
\hline & $13 \mathrm{~mm}$ & .508 & .154 & .021 & .683 & 58.7 \\
\hline \multirow[t]{2}{*}{ Alternative 4} & $26.7 \mathrm{~mm}$ & .968 & .324 & .031 & 1.323 & 51.9 \\
\hline & $13 \mathrm{~mm}$ & .500 & .208 & .022 & .730 & 62.8 \\
\hline \multirow[t]{2}{*}{ Alternative 5} & $26.7 \mathrm{~mm}$ & 1.068 & .298 & .078 & 1.444 & 56.6 \\
\hline & $13 \mathrm{~mm}$ & .545 & .196 & .054 & .795 & 68.4 \\
\hline
\end{tabular}


The CWQM modeling results provide a clear indication of the benefits with respect to sediment removal efficiency for each of the alternatives. In general, the larger-volume facilities were computed to be able to remove more sediment. It is interesting to note that providing additional extended detention storage in Alternative $2 \mathrm{~A}$ reduced the computed efficiency of this design. This result points out the relative importance of the permanent pool volume compared to the active storage volume.

The CWQM modeling indicated that several of the alternatives could achieve the sediment removal efficiency objectives for Spring Creek. In particular, the modeling results showed that Alternative 2, the preferred alternative, was able to achieve almost $60 \%$ TSS removal for the $13 \mathrm{~mm}$ storm event. Given that greater removal efficiency is expected for the lower-intensity storms that make up most of the annual rainfall events, the overall removal objectives should be met.

A review of Table 16.4 suggests that Alternative 2 would only be able to achieve $41.7 \%$ TSS removal, based on $69.5 \%$ of the MOE guideline volume. This might have led to screening out the preferred alternative.

\subsubsection{Sediment Resuspension and Scour Determination}

The ability of the CWQM to compute velocity vectors within the pond was used to estimate whether sediments would be resuspended during peak-flow conditions. The model was run using the hydrographs for $26.7 \mathrm{~mm}$ event (1-y return period storm) and the 1 in $5 \mathrm{y}$ return period storm hydrographs provided by the City of Toronto.

The results indicated that computed velocities in the pond were not great enough to cause resuspension for the $26.7 \mathrm{~mm}$ event. For the 1 in $5 \mathrm{y}$ event, velocities through the pond did reach computed levels that could cause resuspension of settled sediment.

\subsection{Conclusions}

A storm pond model has been developed that can simulate dynamic water circulation, pollutant concentration and decay, sedimentation patterns, and sediment removal. The application of the model for computing removal of SS is demonstrated in an existing stormwater pond, and the results have been shown to agree with monitored TSS concentrations.

The model can be used to evaluate the sediment-removal efficiency of stormwater facilities, including multiple treatment cell facilities. The model is shown to be particularly useful for estimating the efficiency of retrofit designs or other designs that do not strictly conform to design guidelines. 
The visual representation of circulation patterns and velocities within the stormwater pond allows the pond designer additional insight into the operation of the pond. The circulation patterns and pollutant removal simulations allow the designer to optimize the facility early in the project. Modifications to the pond in terms of bathymetry, shoreline geometry, and inlet-outlet configurations that will reduce dead zones, short circuiting, and bottom scouring can be made and tested at the design stage.

\section{References}

City of Toronto, 1998, Suspended Solids Sample Results for Storm Sewers HP-1 and HP-9 (unpublished, personal communication)

Driscoll, E.D., DiToro, D., Gaboury, D., and Shelly, P., 1986, Methodology for Analysis of Detention Basins for Control of Urban Runoff, U.S. Environmental Protection Agency, Non-point Source Branch, Washington, D.C., EPA440/5-87-001

Gore \& Storrie Limited, 1993, City of Kanata-Monahan Drain Constructed Wetland Pre-Design Report, Consultant's report to the City of Kanata (available from CH2M Gore \& Storrie Limited)

Leendertse, J. J., 1970, A Water Quality Simulation Model for Well Mixed Estuaries and Coastal Seas: Volume 1, Principles of Computation, Rand Corporation, RM6230-RC.

Leendertse, J. J. and E. C. Gritton, 1971, A Water Quality Simulation Model for Well Mixed Estuaries and Coastal Seas: Volume 2, Computation Procedures, Rand Corporation, R-708-NYC.

MOE, Ontario Ministry of the Environment and Energy, 1994, Stormwater Management Practices, Planning and Design Manual, Queen's Printer for Ontario, Toronto, Ontario, ISBN 0-7778-2957-6 
